Ünal, S. / Journal of Yasar University, 2020, 15/60, 772-789

\title{
Hisse Senedi Getirileri Üzerinde Para ve Maliye Politikası Araçlarının Etkisi: Borsa İstanbul Üzerine Bir Araştırma
}

\section{Impact of Monetary and Fiscal Policies' Tools on Stock Returns: A Research in Borsa İstanbul}

\author{
Serkan ÜNAL, Ufuk Üniversitesi, Türkiye, serkan.unal@ufuk.edu.tr \\ Orcid No: 0000-0002-7060-979X
}

\begin{abstract}
Öz: Araştırmada Türkiye'de uygulanan para ve maliye politikalarının Borsa İstanbul'da işlem gören hisselerin getirilerine etkisi incelenmiştir. Çalışmada bağımsız değişkenler olarak para politikasını ölçmek için M3 para arzı / GSYH, maliye politikasını ölçmek için ise faiz dışı bütçe dengesi / GSYH değişsenleri kullanılmıştır. Bağımlı değişken olarak ise Borsa İstanbul'un performansını ölçmek için BISST100 endeksinin getirisi belirlenmiştir. Çeyreklik dönem aralı̆̆ının kullanıldı̆̆ veri setinde $2006.1 C ̧$ ve 2019.3Ç arasındaki zaman dilimi kapsanmıştır. Çalışmada durağanlı̆̆ın tespiti için ADF birim kök testi, değişkenler arasındaki ilişkinin ve gecikme sürelerinin tespiti için ARDL sınır testi ve hata düzeltme modeli (ECM), yapısal kırllmaların sonuçlara etki edip etmediğini anlamak için ise CUSUM ve CUSUM x2 testleri uygulanmıştır. Araştırma bulgularına göre bütçe dengesindeki negatif yönlü değişimler ve M3 para arzındaki artış istatistiksel olarak anlamlı bir şekilde BİST100 endeksi üzerinde pozitif etkiye sahiptir.
\end{abstract}

Anahtar Kelimeler: Faiz Oranı, Parasal Genişleme, Para Politikası, Maliye Politikası, Hisse Senetleri Piyasası

JEL Siniflandırmasi: G14, E44, H6

\begin{abstract}
In this study, the effects of monetary and fiscal policies on the stock market were examined in Turkey. M3 / GDP was used to measure monetary policy and primary budget balance / GDP was used to measure fiscal policy as independent variables. As a dependent variable, the return of the BIST10O index was determined to measure the performance of Borsa Istanbul. In the data set, the period between 20061Q and 20193Q is covered. ADF test is used to test the stationarity of variables. ARDL boundary test and ECM were used to determine the short-term and longterm relationships between variables. Finally, CUSUM and CUSUM $x 2$ tests have been implemented to understand whether structural breaks affect the results of the study. According to the research findings, negative changes in the budget balance and the increase in the M3 money supply have a statistically significant positive effect on the BIST100 return index.
\end{abstract}

Keywords: Interest Rate, Monetary Expansion, Monetary Policy, Fiscal Policy, Stock Market

JEL Classification: G14, E44, H6

\section{Giriş}

Maliye politikasının ekonomik aktivite üzerindeki etkisi ekonomi kuramının önemli tartışma alanlarından biridir. $\mathrm{Bu}$ etkiler günümüzde üç farklı popüler şekilde modellenebilmektedir. $\mathrm{Bu}$ modeller Keynesyen, Klasik ve Ricardocu yaklaşımlardır. Keynesyen kamu mali dengesinde bozulmanın ekonomik aktiviteyi pozitif yönde etkileyeceğini savunmaktadır. Ricardocu yaklaşıma göre ise kamu mali dengesi ile ekonomik aktivite arasında ilişki bulunmamaktadır. Klasik ve Ricardocu yaklaşımlar ele alındığında kamu bütçe dengesinin açık vermesi sonucu ekonomik aktivitenin etkilenmemesi ya da olumsuz yönde etkilenmesi durumu söz konusudur.

Makale Gecmiși / Article History

Başvuru Tarihi / Date of Application : 22 Nisan / Nisan 2020

Kabul Tarihi / Acceptance Date : :24 Mayis / May 2020

(C) 2020 Journal of Yaşar University. Published by Yaşar University. Journal of Yaşar University is an open access journal.

There is no conflict of interest or ethical concern regarding this publication. 
Hangi yaklaşımın ele alındığına bağlı olarak hisse senedi piyasasının kamu mali dengesine tepkisi önemli ölçüde değişmektedir (Foresti ve Napolitano, 2017:296).

2008 global finans krizi enflasyonun bütün dünyada oldukça düşük düzeyde seyrettiği bir dönemde yaşanmıştır. Bu krizin ardından peşi sıra ABD, Avrupa Birliği ve Japonya merkez bankaları parasal genişlemede dozu artırmış ve finansal krize likidite ile müdahale etmişlerdir. Özellikle Avrupa Birliğine üye ülkelerde krizden sonra yıllar geçtiği halde istenen büyüme oranlarına ulaşılamaması parasal genişlemenin devam etmesini gerektirmiş ve bazı Avrupa Birliği ülkelerinde negatif faizler söz konusu olmuştur (International Monetary Fund, 2020).

Günümüzde para ve maliye politikalarının sermaye piyasaları üzerindeki etkisi önemli bir tartışma konusu oluşturmaktadır. Her ülkenin makro ekonomik dinamiklerinin farklı olması, uygulanan politikaların da farklı sonuçlar doğurmasına neden olmaktadır. Bu nedenle Türkiye örneğini ele alan bu çalışmada para politikası ve maliye politikası bir arada kullanılarak ve 2006 ile 2019 arasındaki son dönemdeki veriler analiz edilerek kamunun uyguladığı politikaların BİST100 endeksine ne ölçüde yansıdığı araştırılmıştır.

Merkez bankası faiz oranları ile döviz kuru arasındaki ilişkiyi inceleyen çalışmalara literatürde sıklıkla rastlansa da (Erdoğan ve Yıldırım, 2011; Kayhan vd., 2013; Eryüzlü, Bayat ve Taşar, 2019; Kılcı, 2019) para politikası ile hisse senedi piyasaları arasındaki ilişkiyi (Aktaş vd., 2009; Duran, Özlü ve Ünalmış, 2010) ve maliye politikası ile hisse senetleri arasındaki ilişkiyi (Tekeli, 2007) inceleyen çalışmalar az sayıda bulunmaktadır. Literatürdeki çalışmalar daha çok merkez bankası karar değişikliklerinin Borsa İstanbul endeksine etkisini incelemekte, değişken olarak ise daha çok faiz oranını kullanmaktadırlar. Merkez bankasının faiz kararları sıkı ya da geniş̧leyici para politikası uygulama noktasında tek başına belirleyici değildir. Aynı zamanda piyasanın iştahı da devreye girmekte ve uygulanan para politikasının ne kadar sıkı ya da geniş̧leyici olduğu para arzındaki değişimden belli olmaktadır. $\mathrm{Bu}$ nedenle bu çalışmada daha önce Sayılgan ve Süslü (2011:82) ve Hsing (2013:20) tarafından da kullanılan para arzı verisi tercih edilmiştir. Sayılgan ve Süslü (2011:73) tarafından yapılan çalışma, birçok farklı ülkedeki makro ekonomik verinin borsa endekslerine etkisini incelediği için doğrudan para ve maliye politikalarına uygun bir model kurgulanmamıştır. Bu çalışmada ise doğrudan para ve maliye politikalarının sonuçları üzerinde durulmuştur. Bütçe açıkları ile BIST100 performansı arasındaki ilişki yine az işlenen konulardan biridir. Çalışmada maliye politikasının BİST100 üzerindeki etkisini ölçmek için daha önce Tekeli (2007:215) tarafından da kullanılan bütçe açığı değişkeni tercih edilmiştir.

Son yıllarda dünya ekonomilerinde yaşanan yapısal dönüşümün hızı düşünüldüğünde, bu çalışmanın gerek son yıllardaki veriyi içermesi gerekse bu araştırmada kullanılan değişken seçimleri anlamında literatüre katkı sunacağı düşünülmektedir. 
Çalışmanın ikinci bölümünde para ve maliye politikalarının Türkiye ve diğer ülkelerde nasıl geliştiğine dair istatistiki bilgi sunulmuş ve yine konuyla ilgili olarak yapılmış uluslararası çalışmaların sonuçları paylaşılmıştır. Üçüncü bölümde konuyla ilgili olarak yapılmış olan çalışmalardan elde edilen sonuçlar özetlenmiştir. Dördüncü bölümde araştırmada kullanılan veri ve yöntem anlatılmış, beşinci bölümde ise araştırmadan elde edilen bulgular sunulmuştur. Altıncı bölüm olan sonuç kısmı ile makale tamamlanmıştır.

\section{Para Ve Maliye Politikalarının Hisse Senetleri Fiyatları Üzerine Etkisi}

Para ve maliye politikaları farklı gündemlere ve yöntemlere sahip olsalar da her iki politikanın nihai hedefinin uzun vadeli sürdürülebilir ekonomik kalkınma olması gerekmektedir. Sürdürülebilir ekonomik kalkınmaya, para politikası fiyat istikrarını sağlayarak destek olurken, maliye politikası kaynakları etkin bir şekilde dağıtarak, gelir ve servet dağılımında dengeyi sağlayarak katkıda bulunmaktadır (Şener,2011).

Para politikasının temel amacını fiyat istikrarını sağlamak oluşturduğu halde 2000'li yıllarda neredeyse dünyanın tamamında enflasyon oranı kontrol altına alınmış, eş zamanlı olarak ise bazı ülkelerde işsizlik oranı oldukça yüksek seviyelere ulaşmıştır (Bkz. Şekil 1 ve Şekil 2). Bu nedenle merkez bankaları enflasyonla mücadele odaklı hareket etmek yerine ekonomik büyümeye odaklı hareket etmek zorunda kalmış, bu durum da para politikasının temel amacını tartışmaya açık hale getirmiştir.

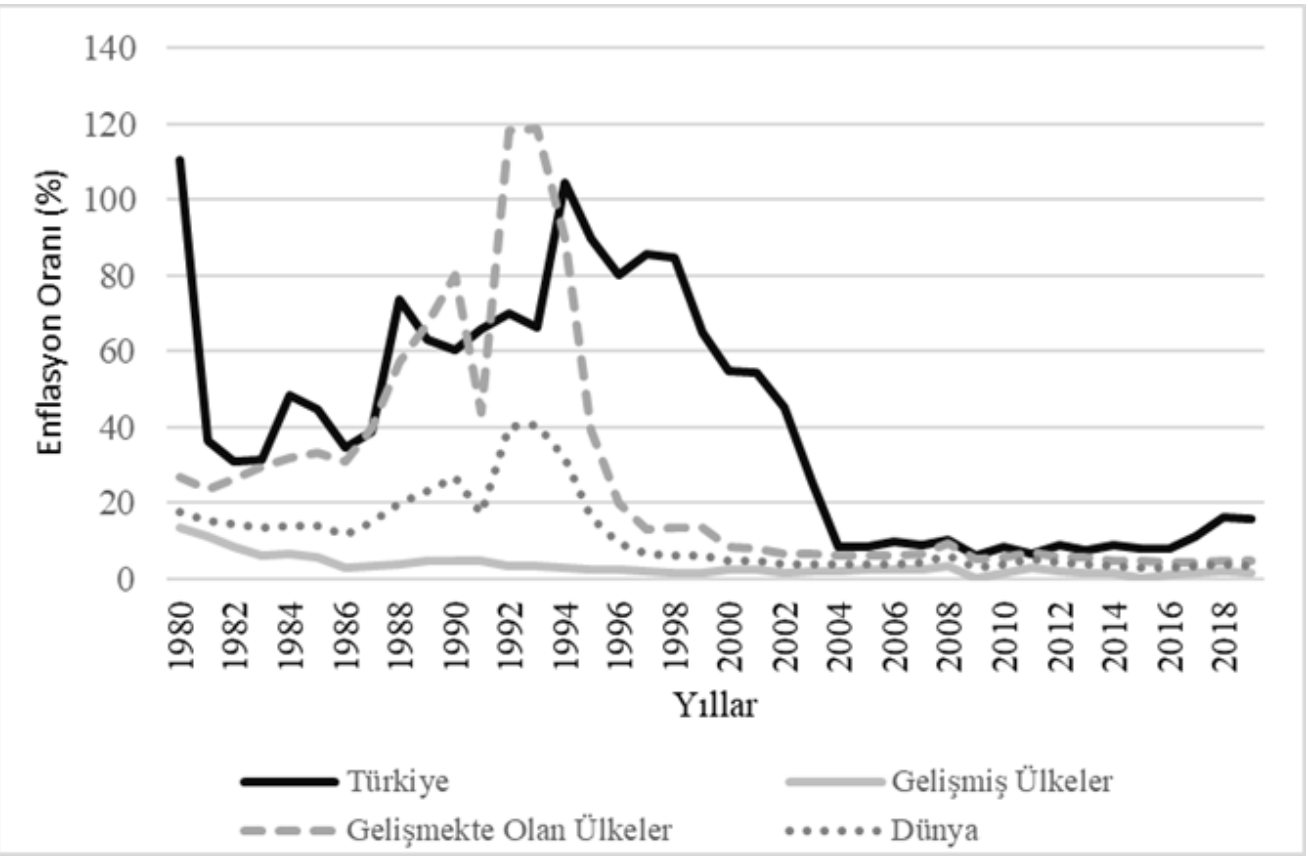

Şekil 1. Türkiye ve Diğer Ülkelerde Enflasyon Oranı (Yı1lık Yüzde Değişim) Kaynak: International Monetary Fund, 2019. (Yazar tarafindan oluşturulmuştur.) 


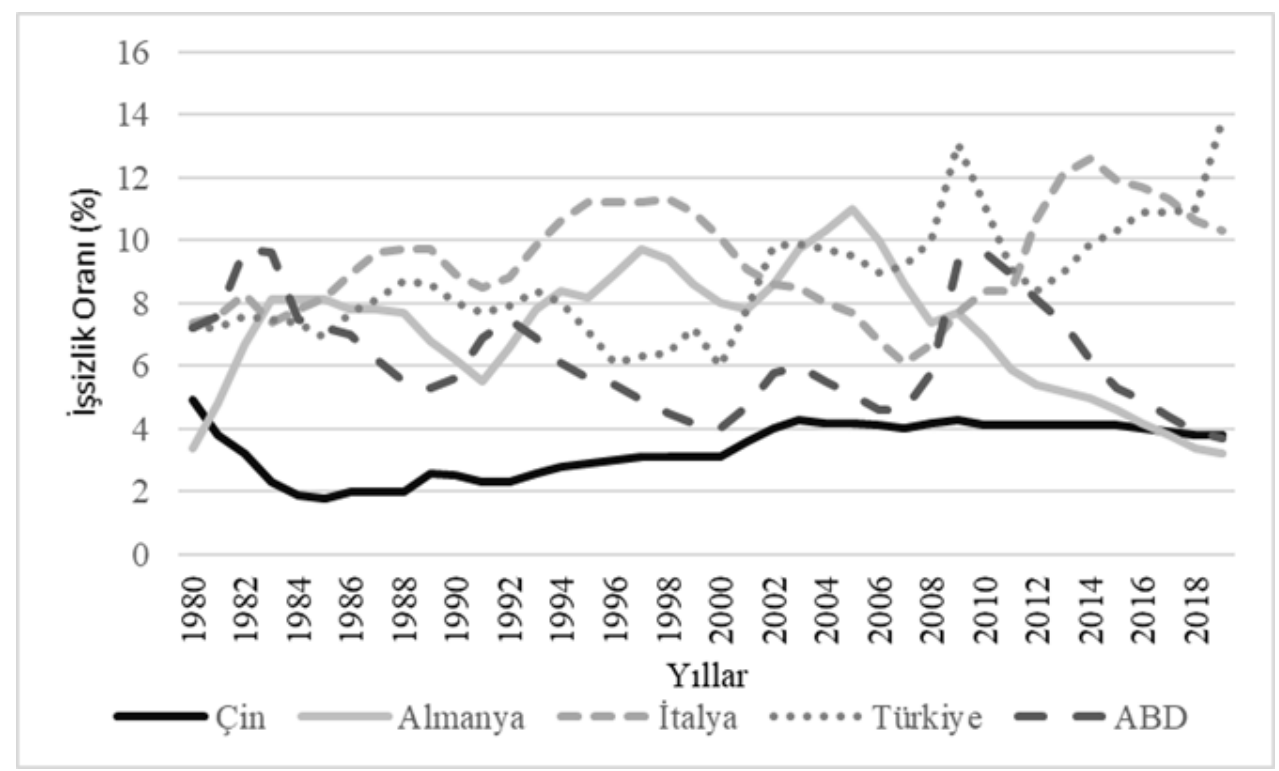

Şekil 2. Türkiye ve Seçilmiş Ülkelerde İşsizlik Oran'ının Gelişimi (\%) Kaynak: International Monetary Fund, 2019. (Yazar tarafindan oluşturulmuştur.)

Özellikle ABD'de 31 Temmuz 2019'da 11 yıl aradan sonra işsizlik oranı düşükken Amerikan Merkez Bankası (Fed)'in faiz indirim kararı alması (Federal Reserve Bank of St. Louis, 2020) ve ardından işsizlik ve hisse senedi endeksleri gibi başlıca ekonomik ve finansal göstergeler iyi durumdayken faiz indirimlerine devam etmesi önemli bir politika değişikliği oluşturmuştur. Diğer yandan ekonomik olarak büyümeyi istediği seviyeye taşıyamayan Avrupa Birliği’nde ise faiz oranları çok daha düşük seyretmektedir. 2014'den itibaren negatif faiz uygulayan Avrupa Merkez Bankası (ECB) 2019 Eylül'ün de faiz oranlarını -\%0,5'e kadar düşürmüştür (European Central Bank, 2020).

Türkiye'de durum dünya genelinden farklı seyretmektedir. Şekil 1'de görüldüğü üzere Türkiye enflasyon sorununu henüz tam olarak çözememiş ülkelerden biridir. Türkiye'de 2009 y1lına kadar uygulanan yüksek faiz ile enflasyon tek haneye indirilmiş ardından daha esnek bir para politikası uygulaması başlamıştır. Düşük faiz politikası dışında diğer enstrümanlar da kullanılmış, kredi garanti fonu ile kobilere sağlanan kredi miktarı 2017 sonunda 221 milyar TL'yi bulmuştur (Kredi Garanti Fonu, 2018). Bunun sonucunda döviz kurlarında hareketle birlikte 2018 yılında enflasyon oranında sert bir artış gerçekleşmiştir. Takip eden dönemde Türkiye Cumhuriyet Merkez Bankası (TCMB) gecelik borç verme faiz oranları önce 01.06.2018'de \%9.25'den \%16,5'e sonrasında ise takip eden üç ilave faiz artışıla 21.09.2018'de \%25,5'e kadar taşınmıştır. Aynı dönemde politika faiz oranı ise \%24'e kadar yükseltilmiştir. Faizlerdeki sert yükseliş sonuç vermiş ve yıllık TÜFE endeksi değişim oranı Ekim 2018'de ulaştığı maksimum değer olan \%25,24'den hızlı bir düşüş eğilimine girmiş ve Ekim 2019'da \%8.55'e kadar düşmüştür. Enflasyonun hızla kontrol altına alınmasının ardından TCMB yeniden esnek politikaya geçiş yapmış ve Temmuz 2019'dan başlayarak Ocak 2020'ye kadar devam eden 
süreçte sert faiz indirimleri ile politika faiz oranını \%24'den $\% 11,25$ 'e, gecelik borç verme faiz oranını ise \%25,5'den \%11.25'e kadar indirmiştir (TUIK, 2020).

Para politikasının hisse senetleri performansına olan etkisi geçmişte birçok akademik çalışmada ele alınmıştır. Rozeff (1974:245), Patelis (1997:1951), Thorbecke (1997:635), Conover, Jensen ve Johnson (1999:38), Neri (2004:23), Bernanke ve Kuttner (2005:1221) ve Bjørnland ve Leitemo (2009:275) tarafından yapılan araştırmalarda merkez bankaları tarafından uygulanan faiz oranlarındaki düşüşün hisse senetleri fiyatlarına olumlu yönde yansıdığı bulunmuştur. Diğer yandan Black (1987:115) ve Durham (2005:83) tarafından yapılan araştırmalarda para politikasındaki değişim ile hisse senetleri fiyat performansı arasında bir ilişki bulunmadı ̆̆ bildirilmiştir.

Durham'ın (2005:84) dikkat çektiği üzere bu konuda yapılan araştırmalarda örneklem seçimi sonuca önemli ölçüde yansımaktadır. Gerek sosyolojik gerek ekonomik gerekse sermaye piyasalarının yapısının ülkeler arasında önemli farklılıklar oluşturması, aynı ülkede bile konjonktürel değişim nedeniyle merkez bankalarının faiz politikalarının yatırımıı açısından farklı dönemlerde farklı şekilde tepkiye maruz kalması söz konusu olmaktadır. Örneğin, Türkiye’de 2002-2007 arasında uygulanan sıkı para ve maliye politikası sermaye piyasaları açısından oldukça olumlu sonuç vermiş ve beklenenin aksine bu dönemde hisse senetleri piyasasında ciddi bir yükselme kaydedilmiştir.

Şekil 3'de BİST100 endeks değerleri TÜFE endeksi ile Şubat 2020 tarihine taşınarak reel gelişimi gösterilmiştir. 2002'den 2006'ya kadar geçen dört yılda faizlerde azalış eğilimi hakimken BİST100/TÜFE değerinin de yükseldiği görülmektedir. Her ne kadar faizler düşüş eğiliminde olsa da bu dönemde Şekil 3'de gösterildiği üzere yüksek oranda reel faiz uygulandığı atlanmamalıdır. 2006 ikinci yarısında faizler tekrar artırılmaya başlanmış ve bu dönemde BİST100/TÜFE endeks değerinde belirgin bir düşüş yaşanmıştır. Ardından 2008 küresel finans krizine kadar faiz oranları yatay seyretmiş ve bu dönemde reel BİST100/TÜFE endeksinde yükseliş trendi hâkim olmuştur. Küresel finans krizinde BİST100/TÜFE endeksi çok sert tepki vermiş ve \%65'e varan bir kayıp yaşamıştır. Finansal kriz sırasında artan döviz kurlarının etkisiyle TCMB'nin ilk tepkisi faiz artırma yönünde gerçekleşmiş olsa da sonrasında dünyadaki önemli merkez bankalarıyla birlikte TCMB'de faizleri indirmeye başlamıştır. 2009 ve 2010'un ilk yarısında BİST100 yaraları büyük ölçüde sarmış ve kriz öncesi seviyeye yükselmiştir. 2011 sonlarına doğru tekrar BİST100/TÜFE endeksinde düşüş, enflasyonda ise yükseliş eğilimi başlamıştır. TCMB'nin 2011 sonundaki müdahalesi ile gecelik borç verme faizi \%9'dan \%12,5'e yükseltilmiş ardından da hem enflasyon düşme eğilimine girmiş hem de BİST100 reel endeksi artmaya başlamıştır. Daha sonrasında 2017'ye kadar faizlerde ve BİST100 endeksinde yatay seyir devam etmiş, 2017'de Kredi Garanti Fonu ile piyasaya yüksek likidite verilmesi ilk olarak 
ekonomik büyüme hızını artırmış, dolayısıyla BİST100 endeksi 2017 yılı ikinci yarısında önemli bir ralli yaşamıştır. Daha sonrasında 2018'in ikinci yarısında döviz kurlarında sert bir yükseliş gerçekleşmiş, ardından enflasyon oranında yükselişin hızlanarak devam ettiği, BİST100'ün de sert bir şekilde düştüğü bir dönem yaşanmıştır. TCMB bu duruma faizleri yüksek oranda artırarak yanıt vermiş, faizler yüksekken BİST100/TÜFE endeksi dip bir seviyede yatay bir dönem yaşamıştır. 2019 ikinci yarısında ise enflasyondaki düşüşle birlikte TCMB faiz oranları düşürülmüş ve BİST100 endeksi yaşadığı kayıpların bir bölümünü bu dönemde geri almıştır.

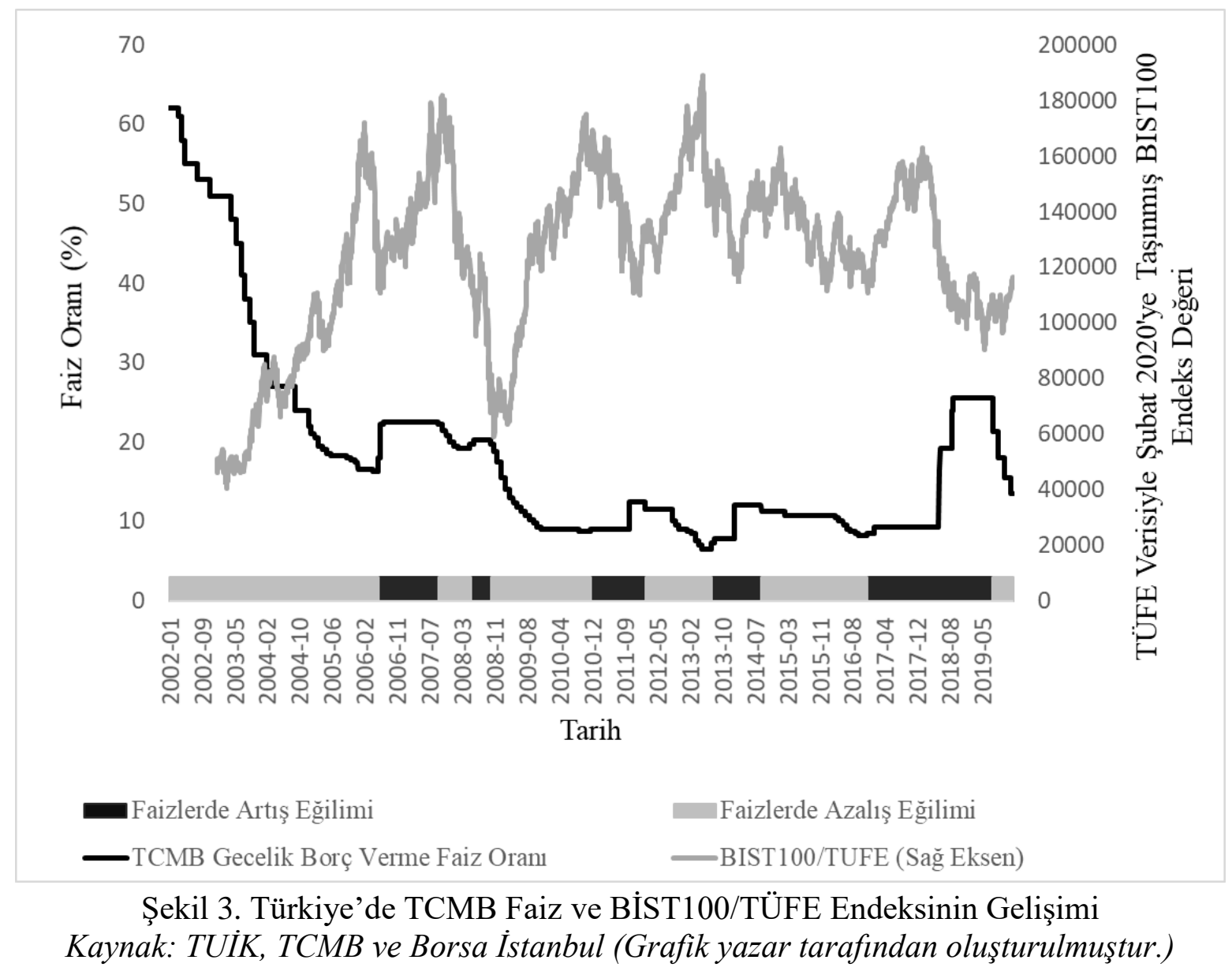

Şekil 4'de gösterildiği üzere, 2008 finansal krizinden sonraki dönemde birçok ülkede yüksek bütçe açıkları söz konusu olmuş ve bu nedenle ülkelerin borç seviyesinde artış meydana gelmiştir. $\mathrm{Bu}$ yüksek borçluluğun gelecekte ülke bütçelerine yansıması ve uzun vadede büyüme oranlarını sınırlaması ihtimali önemli bir risk unsuru oluşturmaktadır. Bu riskin temelinde iki farklı senaryo bulunmaktadır. $\mathrm{Bu}$ senaryolar arasında borcun azaltılması için yüksek vergi oranlarına başvurulması ya da borcun eritilmesi için yüksek enflasyona izin verilmesi bulunmaktadır. Politik açıdan bakıldığında yüksek bütçe açıklarının gelecekte nasıl yönetileceği konusunda belirsizlik söz konusudur. Ekonomik kuramın içinde kamu borcunun oluşturduğu bu tehditler yoğun olarak tartışılmış olsa da nicel araştırmalar vasıtasıyla ya da farklı ülkelerde uygulanan testlerde elde edilen sonuçlar yeterli veriye ulaşılamaması nedeniyle zayıf ve güçsüzdür (Croce vd., 2019:206). 
Türkiye kamu borcu miktarı açısından diğer ülkelerden ayrışmış, özellikle 2000'li yılların başında uyguladığı sıkı maliye politikası ile kamu borcunun Gayri Safi Yurtiçi Hasıla (GSYH)'ya kıyasla oldukça düşük bir seviyeye indirmiştir (Bkz. Şekil 5).

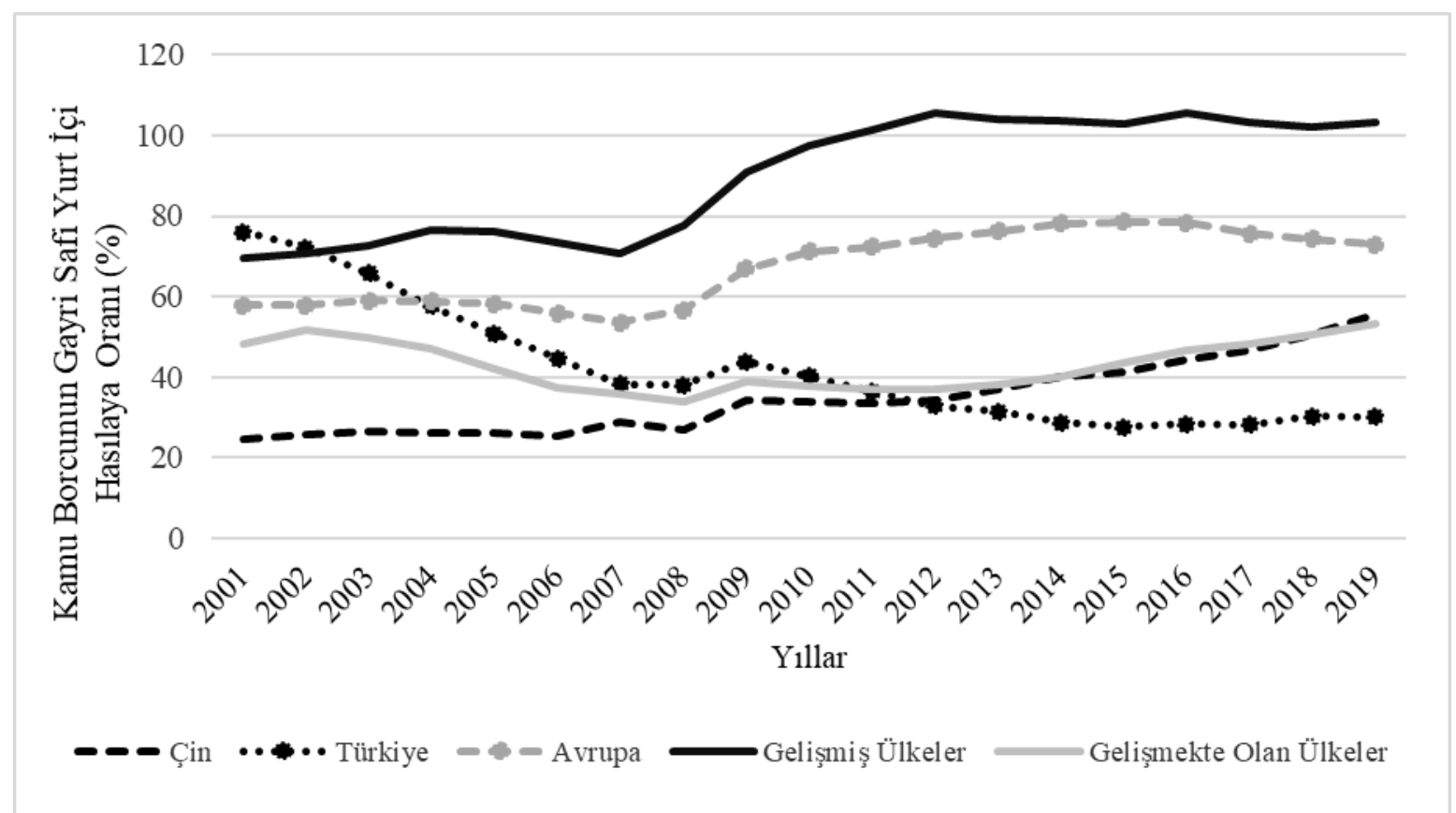

Şekil 4. Türkiye ve Seçilmiş Ülkelerde Kamu Borcunun GSYH’ya Oranının Gelişimi (\%) Kaynak: International Monetary Fund, 2019. (Yazar tarafindan oluşturulmuştur.)

Literatürde birçok çalışmada para politikasının sermaye piyasaları üzerindeki etkisi incelenmiş olsa da maliye politikasının etkisini inceleyen çalışmalar sınırlı sayıdadır (Darrat, 1990; Jansen vd., 2008; Ardagna, 2009; Afonso ve Sousa, 2012; Chatziantoniou vd., 2013; Liu, 2016; Foresti ve Napolitano, 2017; Thanh vd., 2017, Croce vd., 2019). Maliye politikaları birkaç farklı şekilde sermaye piyasalarını etkileyebilmektedir. Keynesyen yaklaşıma göre mali politika ekonomiyi canlandırıcı ve hisse senetleri fiyatlarını yükseltici etkiye sahiptir. Diğer yandan klasik görüşe sahip iktisatç1lar ise kamu borcunun yükselmesinin faizleri yükselteceğini ve kıt olan finansal kaynakların tükenmesine yol açarak özel sektörün finansmana erişimini zorlaştıracağını bildirmektedirler. Kamu harcamalarındaki artış, kısa vadede ekonomik aktiviteyi dolayısıyla da şirketlerin satışlarını ve kar marjlarını artırıcı etkisiyle hisse senedi fiyatlarına olumlu yansımaktadır. Fakat bu artışın uzun vadeli etkileri incelendiğinde faizleri ve risk primini artırıcı etkisiyle de hisse fiyatlarında düşüşe neden olması söz konusudur (Liu, 2016:33). Literatürdeki çalışmalar, maliye politikasının sermaye piyasalarına doğrudan etkisinin zayıf olduğunu fakat dolaylı olarak para politikasıyla birlikte sermaye piyasaları üzerinde güçlü bir etkiye sahip olduklarını göstermektedir (Barbić ve Čondić-Jurkić, 2017:254).

Türkiye'de 2002 -2008 arası uygulanan sıkı maliye politikası ile kamu borç stoku önemli düzeyde azaltılmış, bunun sonucunda kamunun faiz giderleri düşmüştür. Bu süreçte BİST100 endeksi 2008 yılına kadar yükseliş trendinde olmuş ve küresel kriz ile birlikte 2008 yılında önemli 
derecede kayıp yaşamıştır. 2008 sonrası dönemde kamu bütçesi faiz dışı fazla vermemeye başlamış, 2009 y1lında BİST100/TÜFE endeksi kriz öncesi seviyeye varmış olsa da kamunun genişletici maliye politikasına rağmen 2019'a kadar geçen 10 yıllık dönemde yatay bir seyir izlemiştir (Bkz. Şekil 5).

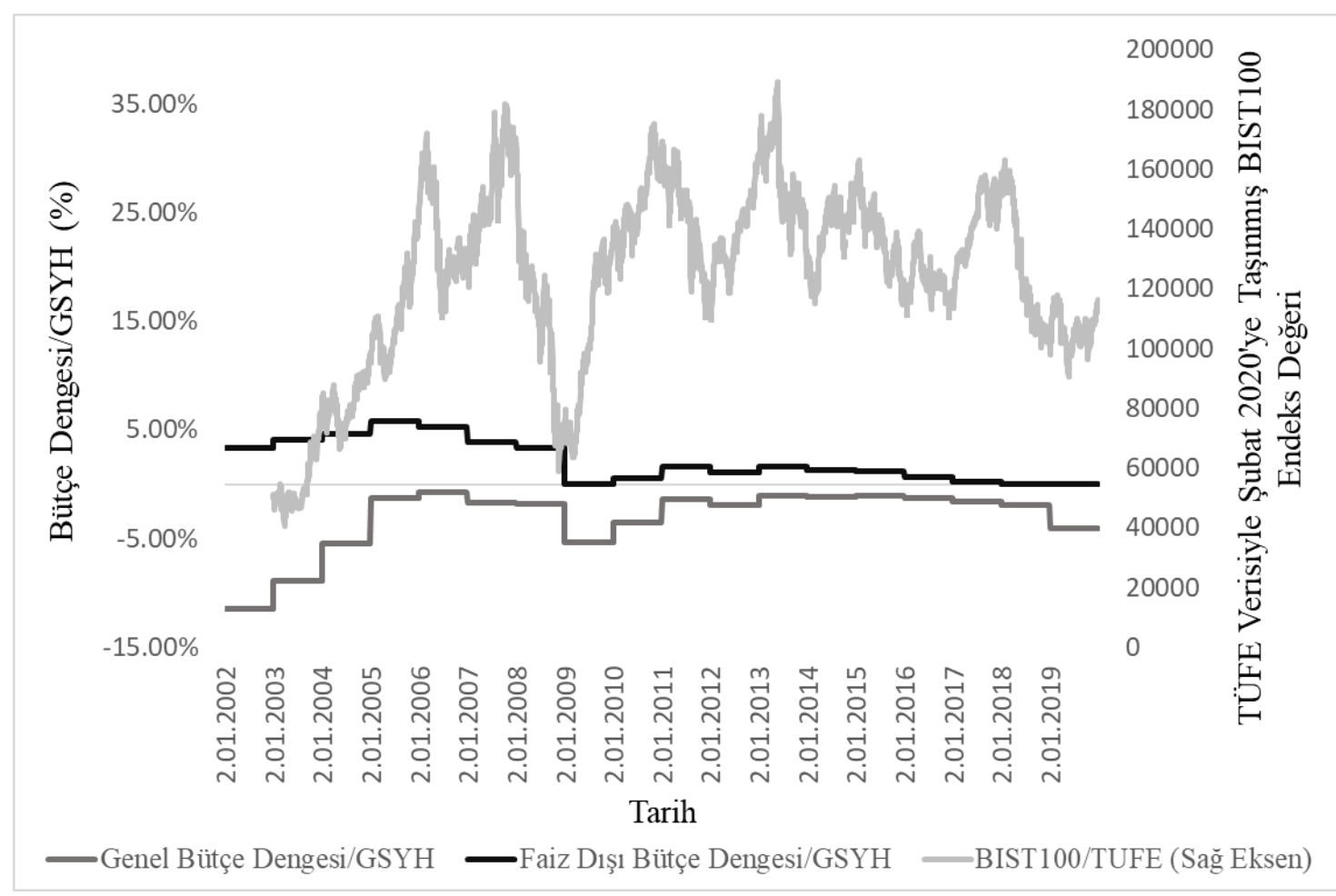

Şekil 5. Türkiye'de Bütçe Dengesi ve BİST100/TÜFE Endeksinin Gelişimi Kaynak: T.C. Hazine ve Maliye Bakanlı̆̆l ve Borsa İstanbul (Grafik yazar tarafindan oluşturulmuştur.)

\section{Para Ve Maliye Politikalarını İnceleyen Çalışmalar}

\subsection{Para Politikasının Hisse Senedi Fiyat Performansına Etkisini İnceleyen Çalışmalar}

Literatürde para politikasının hisse senedi fiyatlarına etkisini doğrudan analiz eden çalışma sayısı sınırlı olduğu için bu bölümde faiz oranları ile hisse senetleri arasındaki ilişkiyi değerlendiren diğer çalışmalara da değinilmiştir.

Aktaş vd. (2009) 2004-2008 yılları arasını kapsayan çalışmalarında Merkez Bankası kararlarını içinde BİST100 endeksi de bulunan değişik mali piyasa enstrümanlarına etkisini araştırmışlardır. Çalışmada merkez bankası kararları sürpriz, beklenen ve sabit olmak üzere ayrıştırılmış, BİST100 üzerinde beklenen kararların olumlu, sürpriz kararların ise olumsuz sonuçlar verdiği bulunmuş olsa da sonuçlar istatistiksel olarak anlamlı değildir.

Duran, Özlü ve Ünalmış (2010) TCMB faiz kararlarının hisse senedi piyasaları üzerine etkisini inceledikleri çalışmalarında 2005-2009 arası döneme ait BİST30, BİST100 ve BİST Tüm endeks serilerini ve 60 adet faiz kararını kullanmışlardır. GMM tahmin yönteminin kullanıldığg 
çalışmadan elde edilen sonuçlara göre politika faiz oranındaki artışlar hisse senedi fiyatlarında negatif etkiye sahiptir.

Özer, Kaya ve Özer (2011) 1996-2009 yılları arasını kapsayan çalışmalarında BİST100 endeksi ile makro ekonomik değişkenler arasında ilişski olup olmadığını kontrol etmişlerdir. En küçük kareler ve Granger nedensellik analizlerinin uygulandığı çalışmaya göre faiz oranları ile BİST100 endeksi arasında istatistiksel olarak \%1 düzeyinde anlamlı ve negatif yönlü bir ilişki tespit edilmiştir.

Sayılgan ve Süslü'nün (2011) yaptığı çalışmada 1999-2006 yılları arasında, içlerinde Türkiye'nin de dahil olduğu 11 farklı ülke için, para arzındaki yüzde değişim, faiz, GSYH, döviz kurundaki yüzde değişim, petrol fiyatındaki yüzde değişim, tüketici fiyat endeksindeki yüzde değişim ve Standard and Poors 500 endeksindeki yüzde değişimin hisse fiyatlarına etkileri incelenmiştir. Panel veri setinin kullanılarak havuzlanmış en küçük kareler ve sabit etkiler modellerinin uygulandığı çalışmada faiz değişkeni ile borsa endeksleri arasında istatistiksel olarak anlamlı bir ilişki tespit edilememiştir.

Makroekonomik değişkenlerin hisse fiyatları üzerine etkisini inceleyen bir diğer çalışma ise Kaya, Çömlekçi ve Kara (2013) tarafından yapılmıştır. Çoklu doğrusal regresyon modeli kullanılan çalışmada piyasa faiz oranı ile BİST100 endeksi arasında ters yönlü ve istatistiksel olarak anlamlı sonuç elde edilmiştir.

Hsing (2013:23) yapmış olduğu çalışmada bütçe açığı ile Polonya hisse senetleri piyasasının performansı arasında istatistiksel olarak anlamlı bir ilişki olmadığını tespit edilmiştir.

Dücan ve Şentürk (2014) 12 aylık vadeli faiz oranları ve USD/TL oranı ile BİST100 endeksi arasındaki ilişkiyi inceledikleri ve 1997-2013 arasındaki dönemi kapsayan çalışmalarında VAR modeli kurgulamış ve Granger nedensellik testini uygulamışlardır. Elde ettikleri sonuca göre faiz USD’yi, USD ise BİST100'ü etkilemektedir.

Güngör ve Kaygın (2015) Borsa İstanbul'da işlem gören imalat sanayi şirketlerini dahil ettikleri çalışmalarında 2005-2011 yılları arazındaki zaman aralığında değişik makro ve mikro ekonomik faktörlerin hisse fiyatlarına yaptıkları etkiyi incelemişlerdir. Dinamik panel veri modelinin uygulandığı çalışmada üç aylık vadeli faiz oranı ile hisse fiyatları arasında negatif yönlü bir ilişki tespit edilmiştir.

Çayır vd. (2015) 2002-2013 arasındaki dönemde TCMB, FED ve ECB'nin uyguladı̆̆ı para politikasının Türkiye'de bankacılık sektörü üzerindeki etkilerini aktif karlılık ve öz kaynak karlılığı değişenlerini kullanarak incelemişlerdir. Markov rejim değişim modelinin uygulandığı çalışmadan elde edilen sonuçlara göre; TCMB'nin uyguladığı para politikası gerek genişleme gerekse daralma dönemlerinde negatif, FED ve ECB'nin uyguladığ 1 para politikaları ise daralma döneminde negatif, genişleme döneminde ise pozitif etkiye sahiptir. 
Barut, Karaoğlan ve Karabayır (2017) 2004-2016 arası dönemde faiz ve döviz kurunun BİST100 üzerindeki etkisini araştırmışlardır. Maki çoklu yapısal kırılmalı eş-bütünleşme testi ve dinamik en küçük kareler yönteminin kullanıldığı çalışmada serilerin uzun dönemde bütünleşik oldukları; dört ve beş kırılma olduğu ve BİST100 ile faiz oranları arasında negatif ilişki olduğu tespit edilmiştir.

Özmen, Karlılar ve Kıral (2017) 1997-2017 arası dönemi kapsayan çalışmalarında döviz kuru, faiz ve enflasyonun BİST100 üzerindeki etkisini incelemişlerdir. Johansen eşbütünleşme analizi, VEC ve Granger nedensellik testinin uygulandığı çalışma sonuçlarına göre BIST100 endeksi ile döviz kuru, mevduat faizi ve TÜFE arasında uzun dönemli ve pozitif bir ilişki bulunmaktadır.

Kaya (2018) para politikası şokları ile hisse senetleri arasındaki ilişkiyi 1998-2016 arasındaki dönemde BİST100 verisini ele alarak incelemiştir. Granger nedensellik testinin uygulandığı çalışmada elde edilen sonuçlara göre para politikası şokları ile BİST100 endeks getirisi arasında çift taraflı nedensellik olduğu bulunmuştur.

\subsection{Maliye Politikasının Hisse Senedi Fiyat Performansına Etkisini İnceleyen Çalışmalar} Tekeli (2007) maliye politikasının önemli bir sonucu olan bütçe açıkları ile hisse senetleri getirileri arasındaki ilişkiyi 1994-2007 arasındaki dönemde konsolide bütçe açığı ve BİST100 endeksi verisini kullanarak incelemiştir. Granger nedensellik, VAR ve eş bütünleşme yöntemlerinin kullanıldığı analizde maliye politikası kararlarının borsayı etkilemediği sonucu bulunmuştur.

Kandır ve Yakar (2012) kurumlar vergisindeki değişikliğin hisse senetleri getirisi üzerine etkisini konu alan çalışmalarında, 29.11.2005 tarihinde yapılan kurumlar vergisi indirimini incelemişlerdir. Çalışmada veri olarak 2004 yılında en çok vergi vermiş olan beş şirketin olay öncesi ve sonrasındaki beş günlük zaman dilimdeki hisse fiyat performansları kullanılmıştır. Araştırma bulgularına göre olay gününde, hisse senedi yatırımcıları anormal bir tepki vermiş ve hisse fiyatları olağan dışı şekilde yükselmiştir.

Yıldırım, Yazgan ve Sakarya (2019) 31.10.2018 tarihinde uygulanan Katma Değer Vergisi (KDV) ve Özel Tüketim Vergisi (ÖTV) indirimlerinin BIST Tekstil, Deri, Ulaştırma ve Ticaret endeksleri üzerindeki etkisini incelemişlerdir. Çalışma sonuçlarına göre olay gününden sonraki on günde ilgili endeksler pozitif yönde olağan dışı getiri elde etmişlerdir.

Polonya hisse senetleri piyasasında M3 para arzı ile hisse senetleri getirileri arasındaki ilişkiyi ele alan Hsing (2013:23) bu ikili arasında aynı yönlü ve istatistiksel olarak anlamlı bir ilişki olduğunu bulmuştur. Para arzı ile hisse senedi getirileri arasındaki ilişkiyi Hindistan borsasında inceleyen Patel (2012:125) makro değişkenler ile hisse performansı arasında uzun dönemli ilişki 
olduğunu bulurken Pakistan borsasında inceleyen Ali vd. (2010:317) bu konuda istatistiksel olarak anlamlı bir ilişki bulmamıştır.

Literatürde Türkiye'de yapılmış birçok çalışmada faiz oranı ile hisse senedi getirileri arasındaki ilişki incelenmiş ve bu ikili arasında negatif bir ilişki olduğu belirtilmiştir (Duran, Özlü ve Ünalmış, 2010:31; Özer, Kaya ve Özer, 2011:176; Güngör ve Kaygın, 2015:163; Barut, Karaoğlan ve Karabayır, 2017:516). Kaya, Çömlekçi ve Kara, (2013:174) faiz oranları ile hisse senetleri fiyatları arasında istatistiksel olarak anlamlı bir ilişki tespit etmemiştir. Faiz oranlarındaki artışın para arzında daralma anlamına geldiği düşünülürse bu çalışma ile literatürdeki diğer çalışmaların sonuçları uyumludur.

\section{Veri ve Yöntem}

$\mathrm{Bu}$ çalışmada para ve maliye politikalarının hisse senetleri getirisi üzerindeki etkisi incelenmiştir. 2001 finansal krizi sonrasında bir dizi önlem alınmış, 2003 yılında Sermaye Piyasası Kurulu (SPK) kurumsal yönetim ilkeleri yayınlanmış, 01.11.2015 tarihinde yayınlanan Bankacılık Kanunu ile Bankacılık Düzenleme ve Denetleme Kurulu (BDDK)'nun yetkileri artırılmış ve yine 2000'lerin başında uluslararası düzeyde geniş çaplı fon akımları oluşmuştur. Yine 1990'larda yüksek çift haneli seviyede yaşanan enflasyon oranı 2000'lerin başında tek haneye kadar indirilebilmiştir. Bu nedenle analiz için hem sermaye piyasasındaki güncel durumu yansıtması hem de geniş bir dönemi kapsaması amacıyla 2006Ç1 ile 2019 Ç3 arasındaki 14 yıllık zaman aralığı ve toplam 55 çeyreklik veri kullanılmıştır. Araştırmada GSYH verisinden faydalanılması ve bu verinin üç aylık zaman dilimlerinde yayınlanması nedeniyle araştırmadaki veri sıklığı çeyreklik olarak belirlenmiştir. BİST100 endeks verisi Borsa İstanbul'dan, TCMB faiz oranları TCMB sitesinden, TÜFE ve GSYH verisi TUİK sitesinden, M3 para arzı, genel bütçe dengesi, ve faiz dışı bütçe verileri T.C. Hazine ve Maliye Bakanlığı sitesinden temin edilmiştir.

Türkiye'deki hisse senetleri performansını ölçen değişken olarak literatürde sıklıkla kullanılan BİST100 dönemsel getiri verisi tercih edilmiştir (Aktaş vd., 2009; Duran, Özlü ve Ünalmış 2010; Tekeli, 2007). Maliye politikası “Faiz Dışı Bütçe Dengesi / GSYH” değişkeni ile, para politikası ise "M3 Para Arzı/GSYH” değişkeni ile ölçülmeye çalışılmıştır (Hsing, 2013). Değişkenlere ait kısaltmalar aşağıda gösterilmiştir.

Çeyreklik BİST100 Endeksi Getirisi : BIST100

Faiz Dışı Bütçe Dengesi / GSYH:BUTCE_DENGESI

M3 Para Arzi/GSYH :M3_GSYH

Çalışmada öncelikle değişskenler üzerinde Genişletilmiş Dickey-Fuller (ADF) birim kök testi uygulanmış, değişkenlerin farklı derecelerde durağan oldukları saptanmıştır. Bu nedenle Pesaran, Shin ve Smith (2001) tarafından geliştirilen ARDL sınır testi yaklaşımı tercih edilmiştir. ARDL 
sınır testi farklı seviyelerde durağan olan değişkenlerde eş bütünleşik ilişki bulunması durumunda kullanılabilmektedir (Tian ve Ma, 2010:495).

Çalışmada ARDL sınır testi uygulanan modele ait (1) numaralı denklem aşağıda gösterilmiştir.

$$
\begin{gathered}
\Delta B I S T 100_{t}=b_{0}+\sum_{i=1}^{j} b_{1 i} \Delta B I S T 100_{t-i}+\sum_{i=0}^{k} b_{2 i} \Delta \text { Butce_Dengesi }_{t-i}+ \\
\sum_{i=0}^{l} b_{3 i} \Delta \mathrm{M} 3 \_G S Y H_{t-i}+b_{4} B I S T 100_{t-i}+b_{5} \text { Butce_Dengesi }_{t-i}+b_{6} \mathrm{M} 3 \_G S Y H_{t-i}+\varepsilon_{t}
\end{gathered}
$$

(1) numaralı denklemde $b_{0}$ sabit terimi, $b_{1}, b_{2}$ ve $b_{3}$ kısa dönemli ilişkiyi; $b_{4}$, $b_{5}$ ve $b_{6}$ uzun dönemli ilişkiyi $\varepsilon_{t}$ ise hata terimini ifade etmektedir.

Eğer değişkenler eş bütünleşik ise hata düzeltme modeli (ECM) uygulanabilir (Shrestha ve Bhatta, 2018:76). Çalışmada uygulanan ECM modeli denklem (2)'de tanımlanmıştır.

$$
\begin{aligned}
& \Delta B I S T 100_{t}=b_{0}+\sum_{i=0}^{j} b_{1 i} \Delta B I S T 100_{t-i}+\sum_{i=0}^{k} b_{2 i} \Delta \text { Butce_Dengesi }_{t-i}+ \\
& \sum_{i=0}^{l} b_{3 i} \Delta{\mathrm{M} 3 \_G S Y H_{t-i}}+\delta E C M_{t-1}+\varepsilon_{t}
\end{aligned}
$$

(2) nolu denklemde $E C M_{t-1}$ hata düzeltme terimini, $\delta$ ise değişkenlerin bir şoka karş1 dengeye yönelme derecesini göstermektedir (Şit ve Karadağ 2019:157).

\section{Bulgular}

Araştırmayla ilgili tanımlayıcı istatistikler Tablo 1'de verilmiştir.

Tablo 1. Tanımlayıcı İstatistikler

\begin{tabular}{lccc} 
& BIST100 & M3_GSYH & BUTCE_DENGESI \\
\hline Ortalama & 0.025 & 0.016 & 1.928 \\
\hline Medyan & 0.018 & 0.020 & 1.932 \\
\hline Maksimum & 0.434 & 0.075 & 2.356 \\
\hline Minimum & -0.298 & -0.032 & 1.397 \\
\hline Standart Sapma & 0.125 & 0.025 & 0.226 \\
\hline Çarpıklık & 0.357 & 0.122 & -0.369 \\
\hline Basıklık & 4.358 & 2.507 & 2.646 \\
\hline Jarque-Bera & 1.393 & 0.878 & 106.024 \\
\hline Olasılık & 0.849 & 0.034 & 2.760 \\
\hline Gözlem & 55 & 55 & 55 \\
\hline
\end{tabular}

Kullanılan değişkenler üzerinde Augmented Dickey Fuller (ADF) testi uygulanmış, düzey ve birinci fark değerleri için sabit ve sabit + trend modellerine uygun olarak durağanlıkları test edilmiştir. Tablo 2'de verilmiş olan sonuçlara göre BIST100 değişkeninin düzeyde durağan olduğu, Butce_Dengesi ve M3_GSYH değişkenlerinin ise birinci farkları alındığında durağanlaştıkları tespit edilmiştir. Değişkenlerin farklı seviyede durağanlık kazanmaları

\begin{tabular}{|c|c|c|c|}
\hline \multicolumn{4}{|c|}{ Sabit } \\
\hline \multicolumn{2}{|c|}{ Düzey } & \multicolumn{2}{|c|}{ Birinci Fark } \\
\hline $\mathrm{t}$ ist & $\mathrm{p}$ & $\mathrm{t}$ ist & $\mathrm{p}$ \\
\hline
\end{tabular}
nedeniyle uygun test yönteminin ARDL sınır testi yaklaşımı olduğu anlaşılmıştır.

\begin{tabular}{|c|c|c|c|}
\hline \multicolumn{4}{|c|}{ Sabit + Trend } \\
\hline & & Biri & \\
\hline $\mathrm{t}$ ist & $\mathrm{p}$ & $\mathrm{t}$ ist & $\mathrm{p}$ \\
\hline
\end{tabular}

Tablo 2. Augmented Dickey Fuller (ADF) Birim Kök Test Sonuçları

\section{Değişken}




$\begin{array}{lllllllll}\text { BIST100 } & -6.028 & 0.000 & -7.940 & 0.000 & -5.968 & 0.000 & -7.857 & 0.000 \\ \text { BUTCE_DENGESI } & -2.878 & 0.055 & -5.097 & 0.000 & -3.114 & 0.114 & -5.200 & 0.001 \\ \text { M3_GSYH } & -2.327 & 0.168 & -3.375 & 0.017 & 0.000 & 0.000 & 0.000 & 0.000\end{array}$

ARDL testi uygulanarak farklı değişkenler için optimum gecikme uzunluğu belirlenmiştir. Şekil 7'de gösterildiği üzere en uygun model diğer modellerden belirgin bir şekilde ayrışan $(4,1,2)$ modelidir.

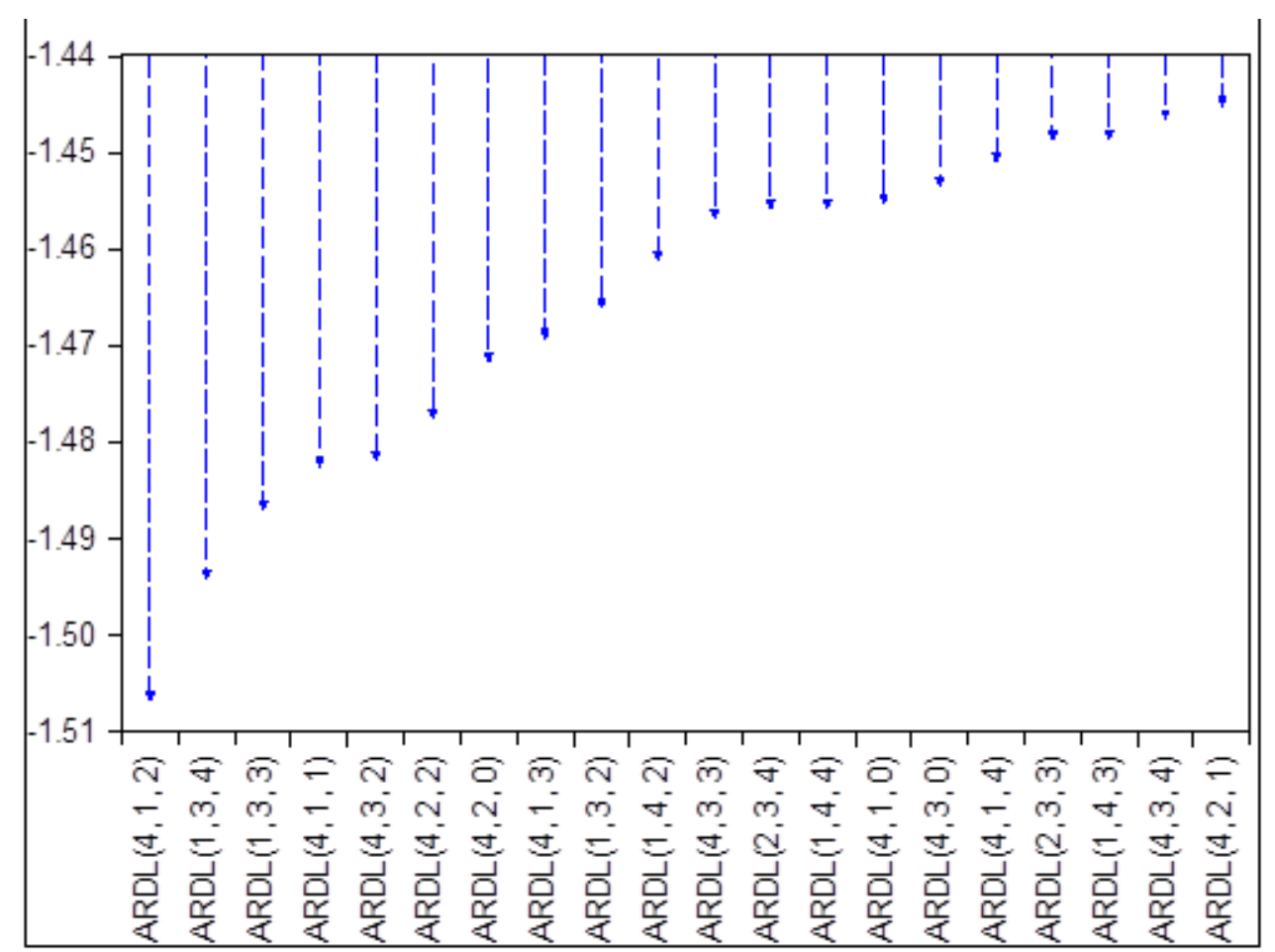

Şekil 7. ADRL Testinde Akaike Bilgi Kriterine Göre En İyi Sonuç Veren 20 Model

Eşbütünleşmenin tespit edilmesi için ARDL sınır testi uygulanmıştır. Test sonuçları Tablo 3'de paylaşılmıştır. Test sonuçlarına göre \%1 anlam düzeyinde denklemde kullanılan değişkenler arasında uzun dönemli ilişki mevcuttur. Bu sonuca göre değişkenler arasında eşbütünleşme ilişkisi olduğundan ARDL modeli uygulanabilmektedir.

Tablo 3. ARDL Sınır Testi Sonuçları

\begin{tabular}{|c|c|c|}
\hline Bağımlı Değişke & Fonksiyon & F İstatistiği \\
\hline BIST100 & F(BIST100] M3_GSYH, BUTCE_DENGESI) & 10.17411 \\
\hline
\end{tabular}

\begin{tabular}{|c|c|c|c|c|c|c|}
\hline \multicolumn{7}{|c|}{ Anlamlılık Düzeyinde Kritik Değerler } \\
\hline \multirow{3}{*}{$\begin{array}{c}\text { Pesaran vd. (2001 } \\
\text { s.300, Tablo CI(ii } \\
\text { Case III }\end{array}$} & \multicolumn{2}{|c|}{$1 \%$} & \multicolumn{2}{|c|}{$5 \%$} & \multicolumn{2}{|c|}{$10 \%$} \\
\hline & $\mathrm{I}(0)$ & $\mathrm{I}(1)$ & $\mathrm{I}(0)$ & $\mathrm{I}(1)$ & $\mathrm{I}(0)$ & $\mathrm{I}(1)$ \\
\hline & 4.13 & 5 & 3.1 & 3.87 & 2.63 & 3.35 \\
\hline
\end{tabular}

Tablo 4'de ARDL (4,1,2) modeline göre elde edilen sonuçlar verilmiştir. Bu sonuçlara göre Butce_Dengesi değişkeni ile BIST100 değişkeni arasında istatistiksel olarak anlamlı ve ters yönlü bir ilişki mevcuttur. Bu sonuca göre bütçe dengesindeki bozulma BIST100 endeksine uzun 
vadede olumlu yönde tesir etmektedir. M3 / GSYH değişkeni ile BIST100 arasındaki ilişkiye bakıldığında ise istatistiksel olarak anlamlı ve aynı yönlü bir ilişki söz konusudur. .

Tablo 4. ARDL(4, 1, 2) Modeli ve Uzun Dönem Katsayılar Bağımlı Değişken: BIST100

\begin{tabular}{ccccc} 
Değişkenler & Katsayı & Std. Hata & t-istatistik & p-değeri \\
\hline BIST100(-1) & 0.236 & 0.121 & 1.955 & 0.058 \\
BIST100(-2) & -0.290 & 0.124 & -2.341 & 0.024 \\
BIST100(-3) & 0.014 & 0.117 & 0.122 & 0.903 \\
BIST100(-4) & -0.317 & 0.120 & -2.646 & 0.012 \\
BUTCE_DENGESI & 1.341 & 0.775 & 1.731 & 0.091 \\
BUTCE DENGESI(-1) & -4.767 & 1.087 & -4.386 & 0.000 \\
M3_GSYH & -0.344 & 0.147 & -2.335 & 0.025 \\
M3_GSYH(-1) & 0.101 & 0.104 & 0.973 & 0.336 \\
M3_GSYH(-2) & 0.237 & 0.100 & 2.384 & 0.022 \\
C & 0.198 & 0.327 & 0.605 & 0.548 \\
R & 0.492 & & & \\
F İstatistiği & 3.874 & & & 0.001
\end{tabular}

Değişkenler arasındaki uzun dönemli ilişski katsayıları bulunduktan sonra kısa dönemli ilişkinin analiz edilmesi için hata düzeltme modeli (ECM) uygulanmıştır. Tablo 5'de belirtilen sonuçlara göre hata düzeltme katsayısı olan $\operatorname{ECM}(-1)$ istatistiksel olarak \%1 düzeyinde anlamlı ve negatif bir değer bulunmuştur. Bu değerin negatif olması ve -1'e yakın olması düzeltmenin ne kadar hızlı yaşanacağını göstermektedir (Kremers, Ericsson ve Dolado, 1992). ECM(-1) değerinin -1'den küçük olması çok sert düzeltmelerin yaşandığı ve dalgalanarak dengenin sağlandığına işaret etmektedir.

Tablo 5. ECM Modelin Tahmin sonuçları

Bağımlı Değişken: BIST100

\begin{tabular}{ccccc} 
Değişkenler & Katsayı & Std. Hata & t-istatistik & p-değeri \\
\hline D(BIST100(-1)) & 0.593 & 0.169 & 3.497 & 0.001 \\
D(BIST100(-2)) & 0.303 & 0.134 & 2.258 & 0.030 \\
D(BIST100(-3)) & 0.317 & 0.108 & 2.942 & 0.005 \\
D(BUTCE_DENGESI) & 1.341 & 0.587 & 2.285 & 0.028 \\
D(M3_GSYH) & -0.344 & 0.082 & -4.213 & 0.000 \\
D(M3_GSYH(-1)) & -0.237 & 0.080 & -2.966 & 0.005 \\
ECM(-1) & -1.356 & 0.193 & -7.021 & 0.000 \\
C & 0.198 & 0.041 & 4.857 & 0.000 \\
R & 0.681 & & & \\
F İstatistĭgi & 11.186 & & & 0.000
\end{tabular}

Son olarak elde edilen sonuçların Türk ekonomisinde yaşanan yapısal kırılmalardan etkilenip etkilenmediğini tespit etmek için sonuçları Şekil 8'de paylaşılan CUSUM ve CUSUM x2 testleri 
yapılmıştır. $\mathrm{Bu}$ testlerden elde edilen sonuçlara göre ARDL modelinde elde edilen sonuçlar yapısal kırılmalardan \%5 anlam düzeyinde etkilenmemektedir.
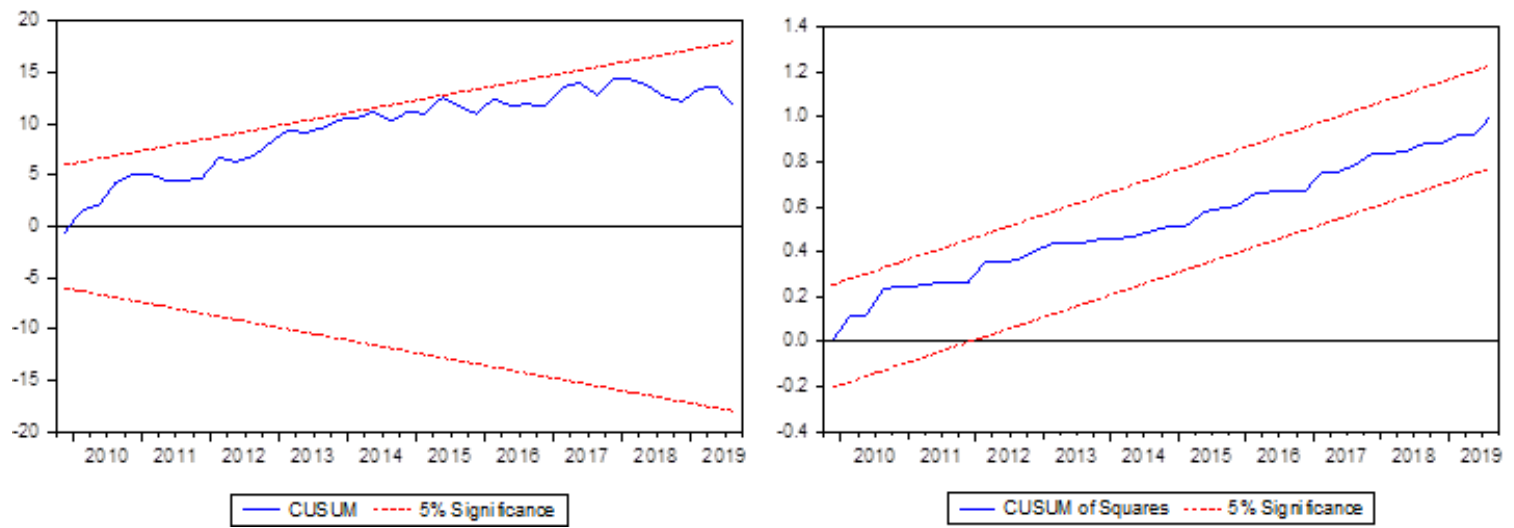

Şekil 8. CUSUM ve CUSUM x² Test sonuçları

\section{Sonuç}

Para ve maliye politikaları, sürdürülebilir bir ekonomik büyüme için önemli bir rol üstlenmekle birlikte sermaye piyasalarını da ciddi şekilde etkileyebilmektedir. Özelleştirmeler, emeklilik fonlarındaki büyüme, bireylerin tasarruf miktarlarındaki artış vb. etkenler hisse senetleri piyasasının performansının giderek daha fazla kişiyi ilgilendirmesini sağlamıştır. Bu durum dolaylı ya da doğrudan politika yapıcılar üzerinde baskı etkisi yaratmaktadır. Bu çalışmada para politikasını temsil eden M3 para arzı / GSYH değişkeni ve maliye politikasını temsil eden faiz dışı bütçe dengesi / GSYH değişkenlerinin BIST100 endeksi ile arasındaki ilişki incelenmiştir.

Türkiye'de özellikle 2010'dan başlamak üzere yüksek reel faiz politikası terkedilmiş ve 2018 döviz kuru şokuna kadar merkez bankasının para politikasında esnek bir yaklaşım sergilenmiştir. 2018 yılı Ağustos ayında döviz kurlarında yaşanan sert yükselişin ardından 2018 Eylül ayında merkez bankası tekrar sıkı para politikasına dönmüştür. 2019 Temmuz ayına kadar devam eden sıkı para politikasının ardından enflasyondaki düşüş ile birlikte merkez bankasının faizler düşürmeye başladığı ve yine aynı dönemde 2020 Şubat ayına kadar BİST100 endeksinin yüksek bir performans sergilediği görülmektedir.

$\mathrm{Bu}$ çalışmada elde edilen sonuçlara göre bütçe dengesi ile hisse senetleri getirileri arasında istatistiksel olarak anlamlı ve ters yönlü bir ilişki mevcuttur. 2002-2007 arası kamu bütçesinin yüksek faiz dışı fazla verdiği dönemde BIST100 endeksi yüksek oranda getiri sağlamıştır. Buna karşın diğer yandan krizlere kamunun bütçe açığı vererek parasal genişleme ile müdahale ettiği ve 2008, 2013 ve 2019'da yaşanan örneklerde kamunun bütçe açı̆̆ındaki artışın gecikmeli olarak Borsa İstanbul performansına pozitif etki ettiği görülmektedir. M3 para arzı / GSYH değişkeni ile BİST100 endeksi arasındaki ilişki incelendiğinde iki değişken arasındaki ilişkinin istatistiksel olarak anlamlı ve aynı yönde olduğu görülmektedir. 
2002-2007 arasındaki kamunun bütçe açığını ciddi oranda azalttığı dönemde Borsa İstanbul'da yüksek performans gözlemlenmiştir. Ardından 2008, 2013 ve 2019 krizlerine yapılan müdahalelerde bütçe açıkları oluşmuş fakat takip eden dönemde yine Borsa İstanbul'da pozitif getiriler söz konusu olmuştur. Kamu bütçe dengesi açısından birbirinin zıttı durumların Borsa İstanbul performansına pozitif yönde yansıdığı görülmektedir. Bu durum kamunun bütçe açıklarının iki farklı açıdan Borsa İstanbul verisine etki ettiği şeklinde yorumlanabilir. Birincisi kamunun bütçe fazlası vermesi, gelecek konusunda ekonomiye güven faktörüyle şirketlerin değerlemesine pozitif yönde yansımaktadır. Ayrıca 2002-2007 arasındaki ralli de kamu bütçe dengesi haricinde Avrupa Birliği’ne giriş süreci gibi diğer faktörler de etkili olmuş olabilir. İkinci etki ise piyasadaki nakit dolaşımdaki para miktarıyla ilgilidir. Kamunun bütçe açı̆̆ı vermesi topladığı vergiden daha çok harcaması anlamı taşımaktadır. Bu durumda piyasadaki likiditeyi destekleyici etkiye sahiptir. Kamunun yurt içinden değil de yurt dişından borçlanması ve yine kamu harcamalarıyla talebi desteklemesi şirketlerin gelirlerindeki kriz nedeniyle oluşan düşüşü telafi etme özelliğine sahiptir. Bu çalışmadan elde edilen sonuçlar kamu bütçe dengesi ile Borsa İstanbul getirisi arasındaki ilişkide ikinci etkinin daha güçlü olduğunu göstermektedir.Maliye politikasına benzer şekilde para politikası ile Borsa İstanbul getirileri arasında da benzer bir ilişki söz konusudur. Merkez bankasının enflasyon ile mücadeleyi tercih ettiği ve yüksek reel faiz ile para arzını sınırlandırdığı dönemlerde Borsa İstanbul getirisnin daha düşük olduğu, Borsa İstanbul'un genişleyici para politikasından faydalandığını göstermektedir. Teorik olarak bakıldığında uzun vadede enflasyon oranındaki düşüşün şirketlerin büyümesine uzun vadede daha olumlu olarak yansıyacağı bilindiği halde Borsa İstanbul performansının kısa vadeli para arzındaki genişlemeye daha olumlu tepkiler verdiği görülmektedir.

$\mathrm{Bu}$ çalışmada elde edilen sonuçlar, sermaye piyasaları ile parasal ve mali politikaların etkileşimi boyutunda Keynesyen para teorisini desteklemektedir. Bundan sonraki araştırmalarda M3 para arzı ve kamu bütçesi dengesi dışındaki diğer değişkenlerin Borsa İstanbul performansına etkisi ele alınabilir. Para arzı noktasında sadece Türkiye'deki değil dünyadaki gelişim ve portföy hareketleri araştırma kapsamlarına dahil edilebilir. 


\section{KAYNAKÇA}

Afonso, A. ve Sousa, R. M. (2012). The macroeconomic effects of fiscal policy. Applied Economics, 44(34), 44394454.

Aktaş, Z., Alp, H., Gürkaynak, R., Kesriyeli, M. ve Orak, M. (2009). Türkiye'de para politikasının aktarımı: Para politikasının mali piyasalara etkisi. Íktisat İsletme ve Finans, 24(278), 9-24.

Ali, I., Rehman, K. U., Yilmaz, A. K., Khan, M. A. ve Afzal, H. (2010). Causal relationship between macro-economic indicators and stock exchange prices in Pakistan. African Journal of Business Management, 4(3), 312.

Ardagna, S. (2009). Financial markets' behavior around episodes of large changes in the fiscal stance. European Economic Review, 53(1), 37-55.

Barbić, T. ve Čondić-Jurkić, I. (2017). Do fiscal variables affect stock market returns in EU countries?. Ekonomski Pregled, 68(3), 253-266.

Barut, A., Karaoğlan, S. ve Karabayır, M. E. (2017). Faiz oranı-döviz kuru ve BİST100 etkileşimi: Makı eşbütünleşme analizi. Kafkas Üniversitesi İktisadi ve İdari Bilimler Fakültesi Dergisi, 8(16), 503-523.

Bernanke, B. S. ve Kuttner, K. N. (2005). What explains the stock market's reaction to Federal Reserve policy?. The Journal of Finance, 60(3), 1221-1257.

Bjørnland, H. C. ve Leitemo, K. (2009). Identifying the interdependence between US monetary policy and the stock market. Journal of Monetary Economics, 56(2), 275-282.

Black, F. (1987). A gold standard with double feedback and near zero reserves. Business Cycles and Equilibrium, $115-20$.

Chatziantoniou, I., Duffy, D. ve Filis, G. (2013). Stock market response to monetary and fiscal policy shocks: Multicountry evidence. Economic Modelling, 30, 754-769.

Croce, M. M., Nguyen, T. T., Raymond, S. ve Schmid, L. (2019). Government debt and the returns to innovation. Journal of Financial Economics, 132(3), 205-225.

Conover, C. M., Jensen, G. R. ve Johnson, R. R. (1999). Monetary conditions and international investing. Financial Analysts Journal, 55(4), 38-48.

Çayır, M., Erer, D., Erer, E. ve Altay, N. O. (2015). TCMB, FED ve ECB para politikalarının türk bankacılık sektörü performans1 üzerindeki etkileri: Markov Switching Yaklaşımı (2002-2013). Maliye Finans Yazıları, $29(104)$

Darrat, A. F. (1990). Stock returns, money, and fiscal deficits. Journal of Financial and Quantitative Analysis, 25(3), 387-398.

Duran, M., Özlü, P. ve Ünalmis, D. (2010). TCMB faiz kararlarinin hisse senedi piyasalari üzerine etkisi. Central Bank Review, 10(2), 23.

Durham, J. B. (2005). More on monetary policy and stock price returns. Financial Analysts Journal, 61(4), 83-90.

Dücan, E. ve Şentürk, M. (2014). Döviz kuru ve petrol fiyati ilişkisi: Küresel Finans Krizi Sonrası Deneyimler. Business and Economics Research Journal, 5(3), 67-80

Erdoğan, S, Yıldırım, D . (2011). Türkiye'de döviz kuru kanalının işleyişi: var modeli ile bir analiz. İstanbul Üniversitesi Siyasal Bilgiler Fakültesi Dergisi , 0 (39) , 94-108

Eryüzlü, H., Bayat, T. ve Taşar, İ. (2019). Türkiye'de para politikası uygulamalarında döviz kurunun önemi parasal durum endeksi analizi. Maliye ve Finans Yazılarl, (111), 51-78.

European Central Bank (2020). Key ECB interest rates, Erişim adresi: https://www.ecb.europa.eu/stats/policy_and_exchange_rates/key_ecb_interest_rates/html/index.en.html

Federal Reserve Bank of St. Louis (2020). Federal Funds Rate, Erişim Adresi: https://fred.stlouisfed.org/series/DFF

Foresti, P. ve Napolitano, O. (2017). On the stock market reactions to fiscal policies. International Journal of Finance \& Economics, 22(4), 296-303.

Güngör, B. ve Kaygın, C. Y. (2015). Dinamik panel veri analizi ile hisse senedi fiyatini etkileyen faktörlerin belirlenmesi. Kafkas Üniversitesi İktisadi ve İdari Bilimler Fakültesi Dergisi, 6(9), 149-168.

Hsing, Y. (2013). Effects of fiscal policy and monetary policy on the stock market in Poland. Economies, 1(3), 1925.

International Monetary Fund (2019). Inflation rate, average consumer prices, Erişim Adresi: https://www.imf.org/external/datamapper/PCPIPCH@WEO/OEMDC/ADVEC/WEOWORLD

International Monetary Fund (2020). Interest Rates, Erişim Adresi: https://data.imf.org/regular.aspx?key=61545855

Jansen, D. W., Li, Q., Wang, Z. ve Yang, J. (2008). Fiscal policy and asset markets: A semiparametric analysis. Journal of Econometrics, 147(1), 141-150.

Kandır, S. Y. ve Yakar, S. (2012). Kurumlar vergisi oranındaki değişikliğin hisse senedi getirileri üzerindeki etkisinin incelenmesi. Maliye Dergisi, 163, 170-186.

Kaya, E. (2018). Para Politikası Şokları ve Hisse Senedi Getirileri İlişkisi. Journal of Accounting, Finance and Auditing Studies, 4(3), 241-257.

Kaya, V., Çömlekçi, İ. ve Kara, O. (2013). Hisse senedi getirilerini etkileyen makroekonomik değişkenler 20022012, Türkiye örneği. Dumlupınar Üniversitesi Sosyal Bilimler Dergisi, (35), 167-176.

Kayhan, S., Bayat, T. \& Uğur, A. (2013). Interest Rates and Exchange Rate Relationship in BRIC-T Countries, Ege Academic Review, 13(2), 227-236. 
Kılcı, E. N. (2019) Geç likidite penceresi faiz oranlarının kredi faiz oranları ve döviz kurları üzerindeki etkisinin analizi: Türkiye örneği. Uluslararasi Afro-Avrasya Araştirmalari Dergisi, 4(8), 13-26.

Kredi Garanti Fonu (2018). $2017 \quad$ Faaliyet Raporu, Erişim Adresi: https://www.kgf.com.tr/images/faaliyet_raporu/2017_kgf_faaliyet_raporu.PDF

Kremers, J. J., Ericsson, N. R. ve Dolado, J. J. (1992). The power of cointegration tests. Oxford Bulletin of Economics And Statistics, 54(3), 325-348.

Liu, Y. (2016). Government debt and risk premia. Available at SSRN 2870973.

Neri, S. (2004). Monetary policy and stock prices: theory and evidence (Vol. 513). Banca d'Italia.

Özer, A., Kaya, A. ve Özer, N. (2011). Hisse senedi fiyatlari ile makroekonomik değişkenlerin etkileşimi. Dokuz Eylül Üniversitesi İktisadi İdari Bilimler Fakültesi Dergisi, 26(1), 163-182.

Özmen, M., Karlılar, S. ve Kıral, G. (2012). Türkiye için döviz kuru, faiz ve enflasyonun hisse senedi getirileri üzerine etkileri. Çukurova Üniversitesi İktisadi ve İdari Bilimler Fakültesi Dergisi, 21(1), 107-120.

Patel, S. (2012). The effect of macroeconomic determinants on the performance of the Indian stock market. NMIMS Management Review, 22(1), 117-127.

Patelis, A. D. (1997). Stock return predictability and the role of monetary policy. The Journal of Finance, 52(5), 1951-1972.

Pesaran, M. H., Shin, Y. ve Smith, R. J. (2001). Bounds testing approaches to the analysis of level relationships. Journal of Applied Econometrics, 16(3), 289-326.

Rozeff, M. S. (1974). Money and stock prices: Market efficiency and the lag in effect of monetary policy. Journal of financial Economics, 1(3), 245-302.

Sayılgan, G. T. D. ve Süslü, C. Y. (2011). Makroekonomik faktörlerin hisse senedi getirilerine etkisi: Türkiye ve gelişmekte olan piyasalar üzerine bir inceleme. BDDK Bankacıllk ve Finansal Piyasalar, 5(1), 73-96

Şener, O . (2011). Fonksiyonel Maliye Politikası. LAÜ Sosyal Bilimler Dergisi , 2 (2) , 3-15

Shrestha, M. B. ve Bhatta, G. R. (2018). Selecting appropriate methodological framework for time series data analysis. The Journal of Finance and Data Science, 4(2), 71-89.

Şit, M. ve Karadağ, H. (2019). Döviz kurunu belirleyen ekonomik faktörler: Türkiye ekonomisi için ARDL sınır testi uygulamasi. International Journal of Economic \& Administrative Studies, (23).

Tekeli, R. (2007). Bütçe açıklarinin hîsse senedî fiyat hareketlerine etkisi: Türkiye örneği. Selçuk Üniversitesi Sosyal Bilimler Meslek Yüksekokulu Dergisi, 10(1-2), 215-230.

Thanh, T. T. T., Thuy, L. P., Anh, T. N., Do Thi, T. ve Truong, T. T. H. (2017). Empirical test on impact of monetary policy and fiscal policy on Vietnam stock market.

Thorbecke, W. (1997). On stock market returns and monetary policy. The Journal of Finance, 52(2), 635-654.

Tian, G. G. ve Ma, S. (2010). The relationship between stock returns and the foreign exchange rate: the ARDL approach. Journal of the Asia Pacific economy, 15(4), 490-508.

$\begin{array}{lllll}\text { Türkiye } & \text { Cumhuriyet } & \text { Merkez } & \text { Bankası. } & \text { (2020). Erişim }\end{array}$ https://www.tcmb.gov.tr/wps/wcm/connect/TR/TCMB+TR/Main+Menu/Temel+Faaliyetler/Para+Politika si/Merkez+Bankasi+Faiz+Oranlari/1+Hafta+Repo

Türkiye İstatistik Kurumu (2020). Erişim Adresi: http://www.tuik.gov.tr/PreTablo.do?alt_id=1014

Yıldırım, H. H., Yazgan, K. F. ve Sakarya, Ş. (2019). Vergi oranlarindaki indirimin sektör endeksleri üzerindeki etkisi: BİST'de bir araştırma. Yeni Ekonomik Trendler ve IŞs Fursatları, 408-420 